\title{
Influences of Chemical Composition and Fineness on the Development of Concrete Strength by Curing Conditions
}

\author{
Jaehyun Lee ${ }^{\circledR}$ and Taegyu Lee * \\ Technology Research and Development Institute, Daelim Industrial, Jongno-Gu, Seoul 03152, Korea; \\ archi0528@daum.net \\ * Correspondence: ninga777@naver.com; Tel.: +82-10-3433-8213
}

Received: 19 November 2019; Accepted: 3 December 2019; Published: 5 December 2019

\begin{abstract}
In this study, the influences of chemical composition and fineness on the development of concrete strength by curing conditions were investigated through performance evaluation of high $\mathrm{SO}_{3}$ Portland cement (HSPC) and ordinary Portland cement (OPC). At the same fineness $\left(3800 \mathrm{~cm}^{2} / \mathrm{g}\right)$, the initial and final setting times of HSPC were 92 and 98 min less than OPC. Early mortar compressive strength was approximately $176 \%$ higher after $24 \mathrm{~h}$. After curing for $15 \mathrm{~h}, 18 \mathrm{~h}$, and $24 \mathrm{~h}$, the maturity of HSPC concrete $(107.4 \%, 109.6 \%$, and $111.7 \%)$ and early compressive strength $(146.4 \%, 170.7 \%$, and $154.5 \%$ ) were higher than measured for OPC concrete. HSPC fineness was $111.8 \%$ higher than $\mathrm{OPC}$, leading to early activation of the hydration reaction. By X-ray fluorescence analysis, the $\mathrm{SO}_{3}$ content of HSPC was $107.9 \%$ that of OPC. The applicable time for HSPC concrete form removal was shorter than that for OPC concrete. The relationships $\mathrm{y}=-10.57 \ln (\mathrm{x})+47.30$ and $\mathrm{y}=-9.84 \ln (\mathrm{x})$ +44.05 were estimated for predicting the early-age strength OPC and HSPC concrete. Therefore, applying HSPC concrete to an actual construction site is expected to shorten the construction period and reduce the heating curing cost in winter compared to OPC concrete.
\end{abstract}

Keywords: chemical composition; fineness; setting time; early compressive strength; high $\mathrm{SO}_{3}$ Portland cement (HSPC); ordinary Portland cement (OPC); form removal time

\section{Introduction}

Concrete is the most commonly used construction material because of its excellent strength and durability [1,2]. After a concrete structure has cured, the removal of the forms used to hold its shape during hardening is the most important part of the management process at construction sites that must adhere to the standards determined during the audit process. Therefore, predicting the early-age strength of concrete by calculating the relationship between the curing temperature and mechanical strength is becoming an increasingly important part of concrete research [3,4]. Several recent publications have employed the maturity method to estimate the compressive strength of different types of concrete, including mass concrete [5,6], steel fiber reinforced concrete [7], sprayed concrete [8], and eco-concrete [9-11]. However, to the best of our knowledge, no previous studies have estimated the compressive strength of field applicable high $\mathrm{SO}_{3}$ Portland cement (HSPC).

The contribution of cement particles to the strength of the concrete is closely related to their size $[12,13]$. Specifically, cement particle size controls the degree of hydration in the early hydration stage; i.e., finer cement particles lead to higher heat of hydration [14,15], with extremely fine cement particles being completely hydrated within $24 \mathrm{~h} \mathrm{[16].} \mathrm{Conversely,} \mathrm{finer} \mathrm{cement} \mathrm{grains} \mathrm{can} \mathrm{affect} \mathrm{the}$ generation of early-age cracks in the cement matrix $[17,18]$. This study evaluated the performance of cement with a higher degree of fineness than ordinary Portland cement (OPC). 
Superplasticizers are also applied to cementitious materials and concrete fabrication to realize significant improvements in machinability, mechanical properties, porosity, and durability. They can provide excellent workability while substantially reducing the water/binder ratio [19-22] and increasing strength. This takes place up to a point beyond which low water/binder ratios can lead to other problems. For example, the degree of hydration of cement minerals may be significantly reduced. Consequently, their ability to directly contribute to cement performance will also be reduced; therefore, the plasticizer addition level must be optimized [23].

Portland cement CEM I is a powdered material made of clinker and gypsum [24]. Gypsum is used to control the hardening time of cement [25], and the mechanical properties (strength, shrinkage, and expansion) of cement can change depending on the amount of gypsum in the matrix [26,27]. Gypsum may be present in small proportions as anhydrite $\left(\mathrm{CaSO}_{4}\right)$ but, owing to instability, rarely as the hemihydrate $\left(\mathrm{CaSO}_{4} \cdot 1 / 2 \mathrm{H}_{2} \mathrm{O}\right)$. Gypsum is present in cement as calcium sulfate dihydrate $\left(\mathrm{CaSO}_{4} \cdot 2 \mathrm{H}_{2} \mathrm{O}\right)$ and is expressed in terms of trioxide sulfate $\left(\mathrm{SO}_{3}\right)$ levels [28]. The $\mathrm{SO}_{3}$ content should be less than $4 \%$ according to European standard EN 197-1 [29] because, in cementitious systems, low $\mathrm{SO}_{3}$ content cannot guarantee sufficient condensation delay, whereas high $\mathrm{SO}_{3}$ content has a significant effect on the cement strength and dimensional stability. Optimal $\mathrm{SO}_{3}$ content ensures maximum strength and minimum shrinkage of the matrix without excessive expansion in water [26,30,31].

According to Kurdowski [32], the optimum $\mathrm{SO}_{3}$ content (\%) can be calculated using one of the following formulas:

$$
\begin{gathered}
\% \mathrm{SO}_{3(\text { Optimum })}=0.556 \cdot \mathrm{Na}_{2} \mathrm{O}_{2}+0.0017659 \cdot \text { Fineness }+0.1072 \cdot \mathrm{Fe}_{2} \mathrm{O}_{3}-3.6004 \\
\% \mathrm{SO}_{3(\text { Optimum })}=0.093 \cdot \mathrm{Al}_{2} \mathrm{O}_{3}+1.71 \cdot \mathrm{Na}_{2} \mathrm{O}_{2}+0.94 \cdot \mathrm{K}_{2} \mathrm{O}+1.23 \\
\% \mathrm{SO}_{3(\text { Optimum })}=6.810^{-5} \cdot \text { Fineness } \cdot \mathrm{C}_{3} \mathrm{~A} \\
\% \mathrm{SO}_{3(\text { Optimum })}=1.841+0.095 \cdot \mathrm{C}_{3} \mathrm{~A}+1.6364 \cdot \mathrm{Na}_{2} \mathrm{O}_{2} .
\end{gathered}
$$

However, as reported by Mohammed and Safiullah [33], and shown in Figure 1, it has been proven through testing that the maximum hydration degree (elapsed time of $72 \mathrm{~h}$ ) and compressive strength (elapsed time of $48 \mathrm{~h}$ ) are increased when $\mathrm{SO}_{3}$ content is approximately $3.0 \%-3.2 \%$.

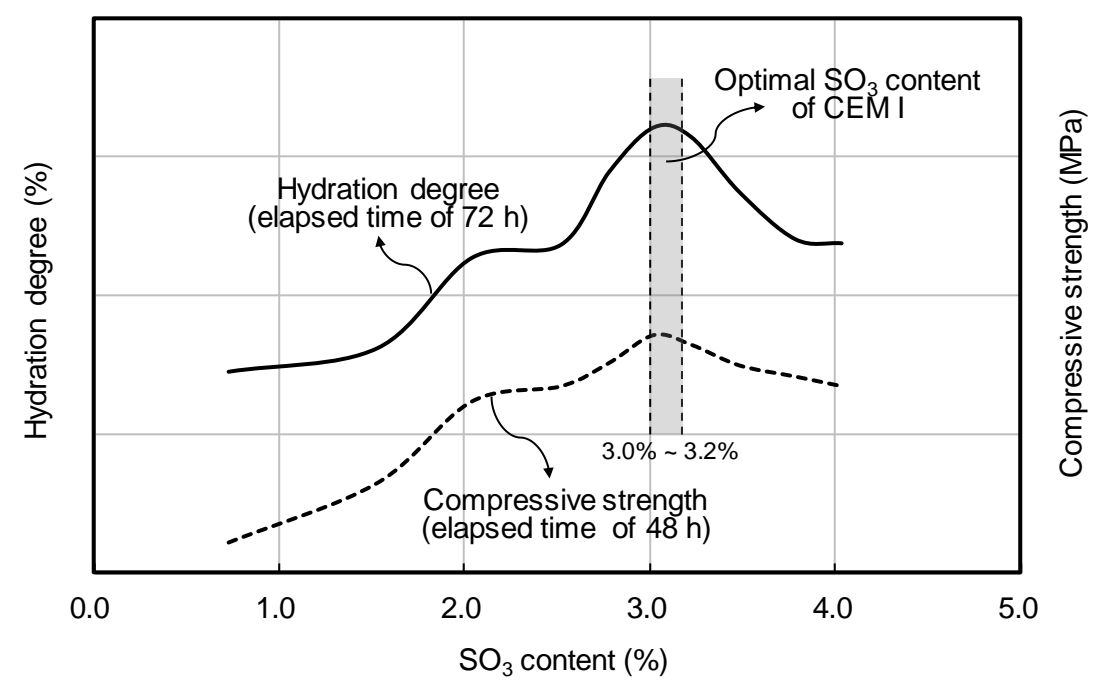

Figure 1. Preliminary test results of the compressive strength of fine cement according to binder weight and curing temperature.

To maximize early compressive strength and apply the findings to construction sites, the research team added gypsum to OPC clinker, increasing $\mathrm{SO}_{3}$ to $3.1 \%$ and improving fineness by $111.8 \%$ $\left(400 \mathrm{~cm}^{2} / \mathrm{g}\right.$ on $\left.3400 \mathrm{~cm}^{2} / \mathrm{g}\right)$. In this study, the new HSPC was evaluated against OPC by setting time and 
early compressive strength according to cement fineness and type in a mortar test (Series I), and slump and air content according to cement fineness and type in a concrete test (Series II). Early compressive strength and maturity were evaluated in the Series II testing. The strength prediction of concrete and the possibility of removing the vertical formwork according to the heat of hydration were applied to the in-place curing of concrete samples in a field test structure.

\section{Experimental Procedure}

\subsection{Materials}

Ordinary type 1 Portland cement and type 2 fly ash (FA) that met the KS L 5201 standard (Portland cement) [34] were used as binders (Table 1). HSPC cement with fineness increased to approximately $111.8 \%\left(400 \mathrm{~cm}^{2} / \mathrm{g}\right)$ was prepared by adding gypsum to a level of $3.1 \% \mathrm{SO}_{3}$ content to ensure the development of early compressive strength. Washed sea sand (40\%) and crushed sand (60\%) were mixed for use as the fine aggregate. Crushed granite aggregate was used as the coarse aggregate. Polycarboxylic superplasticizer was applied to both OPC and HSPC, as the only admixture used.

Table 1. Physical properties of the materials used in the tests. (OPC, ordinary Portland cement; HSPC, high $\mathrm{SO}_{3}$ Portland cement.).

\begin{tabular}{cc}
\hline Materials & Physical Properties \\
\hline OPC & Ordinary Portland cement (density: $3.15 \mathrm{~g} / \mathrm{cm}^{3}$, fineness: $3400 \mathrm{~cm}^{2} / \mathrm{g}$ ) \\
\hline HSPC & High SO 3 Portland cement (density: $3.13 \mathrm{~g} / \mathrm{cm}^{3}$, fineness: $3800 \mathrm{~cm}^{2} / \mathrm{g}$ ) \\
\hline FA & Fly ash (density: $2.20 \mathrm{~g} / \mathrm{cm}^{3}$, fineness: $3850 \mathrm{~cm}^{2} / \mathrm{g}$ ) \\
\hline \multirow{2}{*}{ Fine aggregate } & Crushed sand $60 \%\left(\right.$ density: $2.63 \mathrm{~g} / \mathrm{cm}^{3}$, absorption: $\left.1.30 \%\right)$ \\
\cline { 2 - 2 } & Washed sea sand $40 \%\left(\right.$ density: $2.60 \mathrm{~g} / \mathrm{cm}^{3}$, absorption: $\left.1.34 \%\right)$ \\
\hline Coarse aggregate & Crushed granitic aggregate (size: $25 \mathrm{~mm}$, density: $2.65 \mathrm{~g} / \mathrm{cm}^{3}$, absorption: $\left.0.89 \%\right)$ \\
\hline Admixture & Polycarboxylic superplasticizer-based type (density: $1.26 \mathrm{~g} / \mathrm{cm}^{3}$ ) \\
\hline
\end{tabular}

Table 2 shows the chemical composition of binders used in the tests. HSPC was characterized by higher $\mathrm{SO}_{3}$ content (3.13\%) and loss on ignition (L.O.I.) than OPC. The particle size distributions, obtained using a Mastersizer 2000 (Malvern Panalytical, Seongnam-si, Korea), are shown in Figure 2. The HSPC cement had a mean diameter of $16.31 \mu \mathrm{m}$ and fineness modulus 1.015, while OPC had a diameter of $19.46 \mu \mathrm{m}$ and fineness 1.175; i.e., HSPC had a smaller and finer particle size distribution than OPC. Analysis using a Genesis-2020 scanning electron microscope (SEM, Emcrafts, Gwangju-si, Korea) (Figure 3) confirmed this result, revealing similarly shaped particles, but smaller in the case of HSPC. Crystallinity was analyzed by X-ray diffraction (X'pert3 Powder PW 3050, Malvern Panalytical, Seongnam-si, Korea) (Figure 4); the samples had a very similar crystal structure, except that OPC contained more brushite. Figure 5 shows the particle size distribution curves of the aggregates used in this study.

Table 2. Chemical composition of binders used in the tests. (OPC, ordinary Portland cement; HSPC, high $\mathrm{SO}_{3}$ Portland cement.).

\begin{tabular}{cccccccccc}
\hline \multirow{2}{*}{ Materials } & \multicolumn{8}{c}{ Chemical Composition (\%) } & \multirow{2}{*}{ L.O.I. (1) $^{*}$} \\
\cline { 2 - 8 } & $\mathrm{SiO}_{\mathbf{2}}$ & $\mathbf{A l}_{\mathbf{2}} \mathbf{O}_{\mathbf{3}}$ & $\mathrm{Fe}_{\mathbf{2}} \mathbf{O}_{\mathbf{3}}$ & $\mathbf{C a O}$ & $\mathbf{M g O}$ & $\mathbf{S O}_{\mathbf{3}}$ & $\mathbf{K}_{\mathbf{2}} \mathbf{O}$ & Other & \\
\hline $\mathrm{OPC}$ & 19.82 & 4.85 & 3.30 & 60.34 & 3.83 & 2.90 & 1.08 & 0.86 & 3.02 \\
$\mathrm{HSPC}$ & 19.22 & 4.51 & 3.35 & 61.00 & 4.14 & 3.13 & 1.04 & 0.79 & 2.82 \\
\hline
\end{tabular}

(1) L.O.I.: Loss on ignition. 


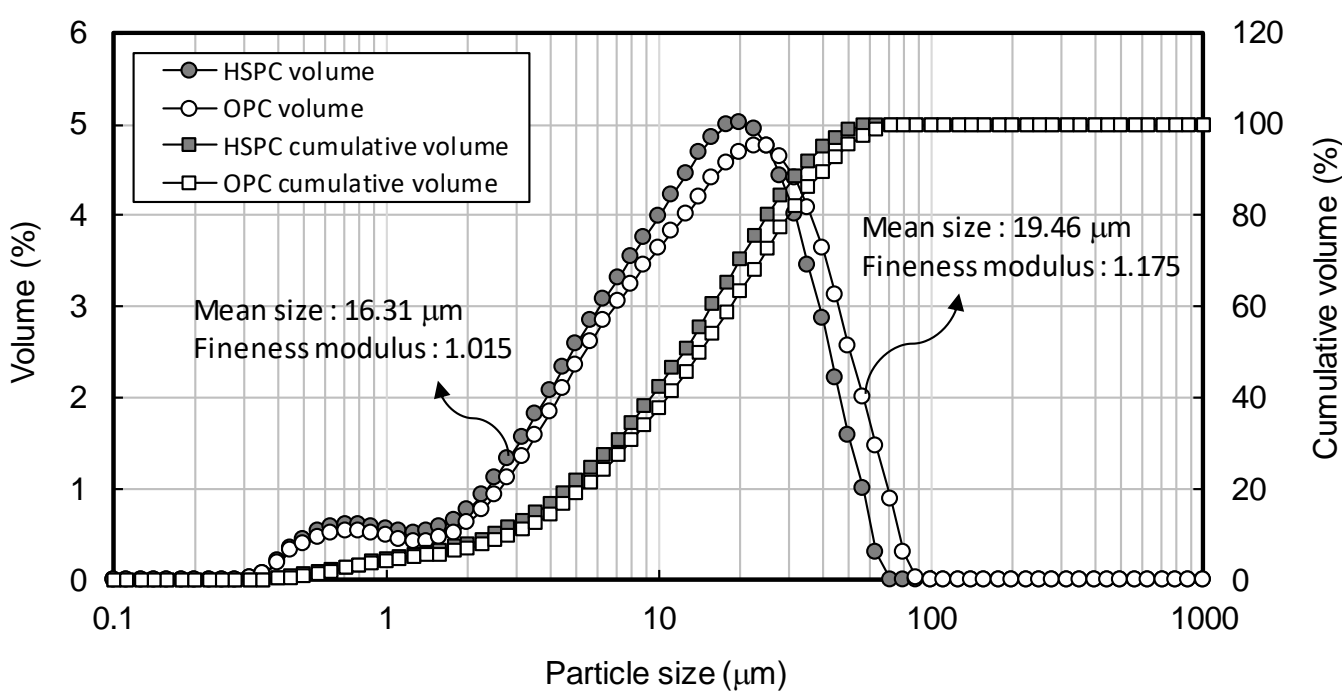

Figure 2. The particle size distribution of OPC (ordinary Portland cement) and HSPC (high $\mathrm{SO}_{3}$ Portland cement).

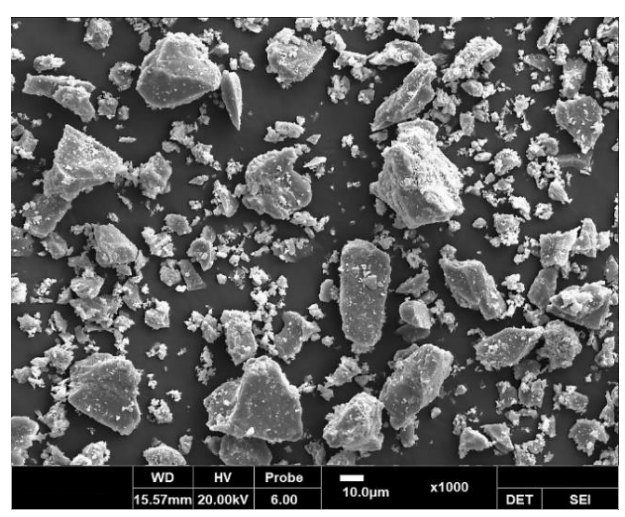

(a)

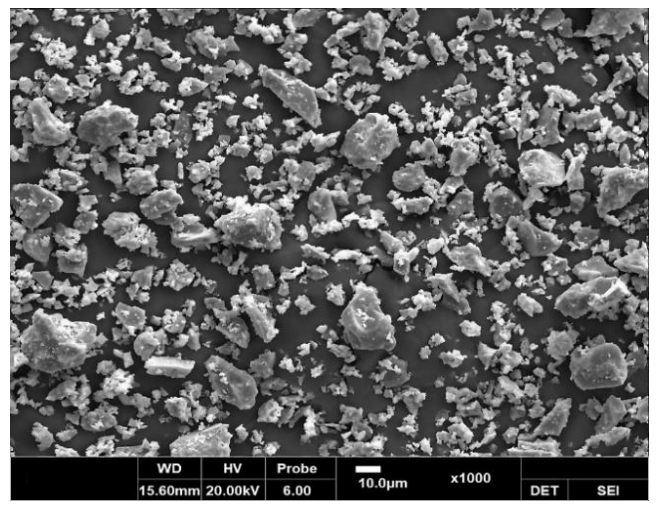

(b)

Figure 3. Scanning electron microscope micrograph: (a) OPC; (b) HSPC. 


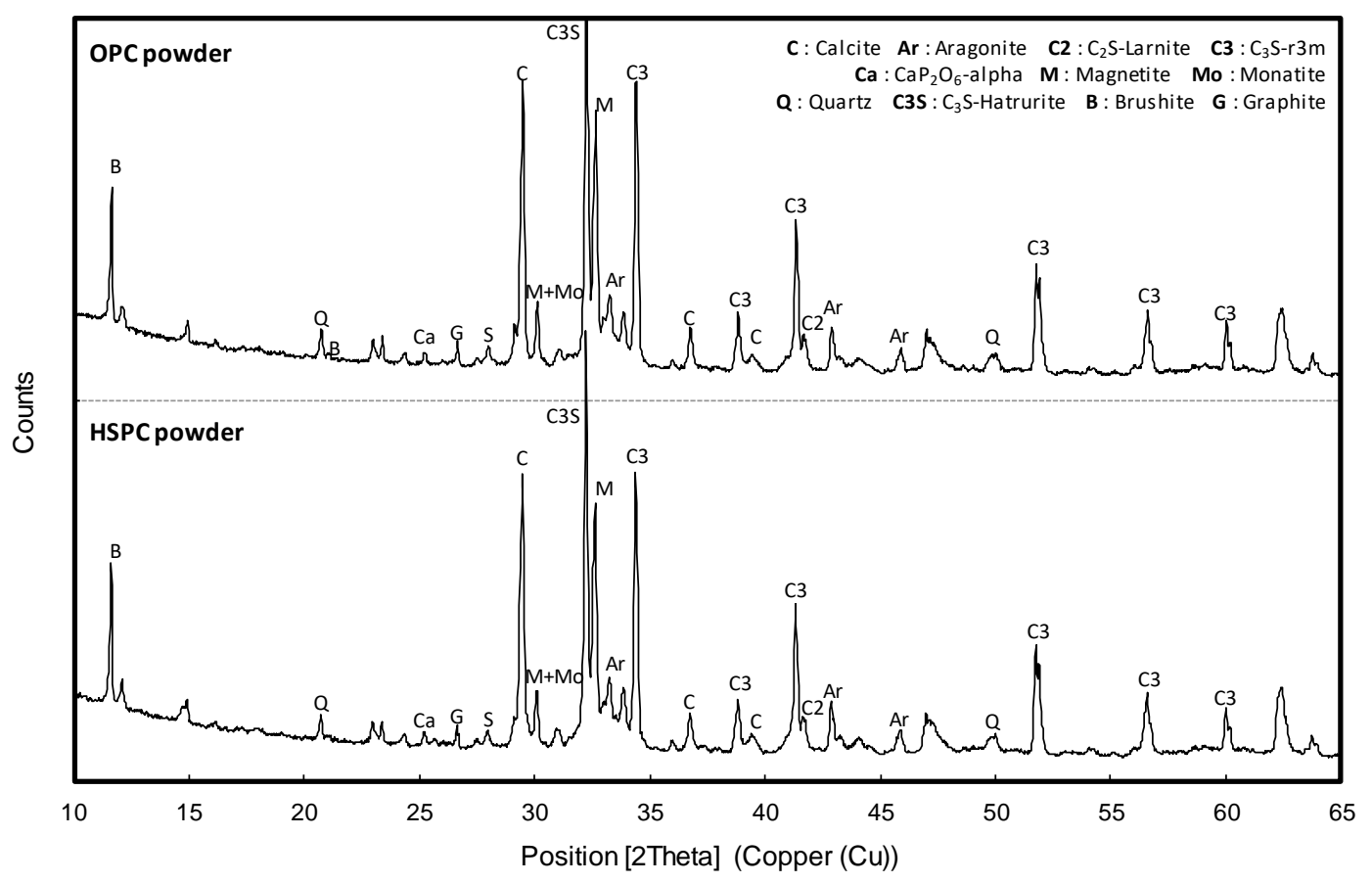

Figure 4. X-ray diffraction patterns of OPC and HSPC.

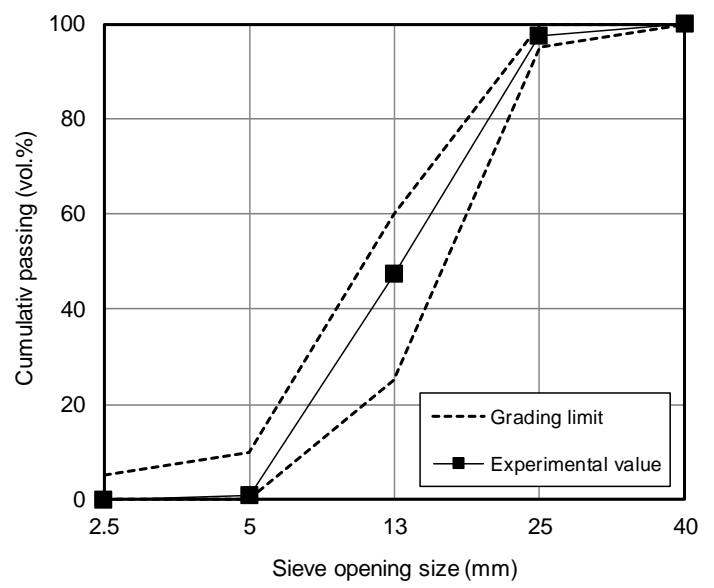

(a)

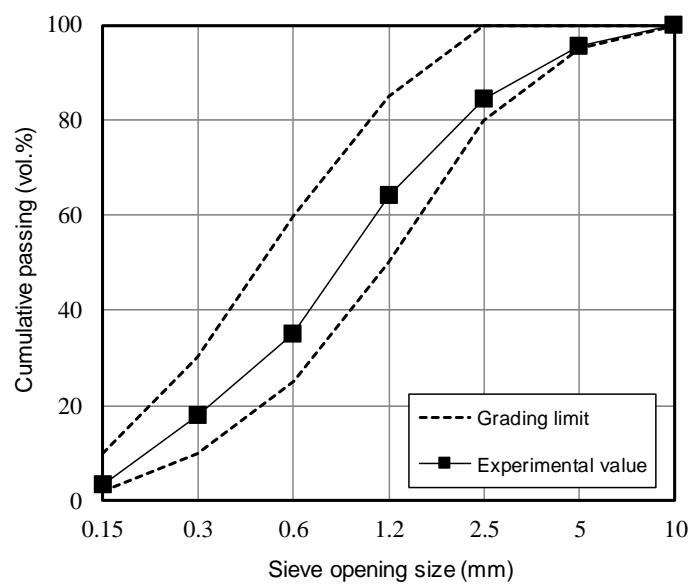

(b)

Figure 5. Particle distribution curves of aggregates used: (a) Coarse aggregates; (b) Fine aggregates. 


\subsection{Experimental Parameters}

Two series of setting time and early compressive strength tests were carried out: Series I (mortar test); Series II (concrete tests). The tests, fineness level settings, and concrete curing conditions for the two types of cement are shown in Table 3. In Series II, cement curing was set to level 3 (chamber, indoor, sealed). All experiments were performed in an environment with air temperature $20 \pm$ $2{ }^{\circ} \mathrm{C}$ and relative humidity $30 \%-40 \%$, as recommended by the National Conference of Standards Laboratories-International (NCSLI). The Series I mortar mixing proportions are summarized in Table 4. Water/cement (W/C) and cement/sand (C/S) ratios (ASTM C778) [35] were set identically for the two types of cement, and the same cement, water, and superplasticizer (admixture, AD) masses were used to make the samples. The Series II concrete mixing proportions are shown in Table 5. The quantities in these were likewise set identically. The binder unit content was fixed at $330 \mathrm{~kg} / \mathrm{m}^{3}$, which corresponded to the compressive strength most commonly used for a typical apartment floor (24 MPa). The ready-mixed concrete was produced by Remicon S companies (Busan, Korea), which delivered the concrete to the construction sites. Ten percent of the total binder quantity was replaced with fly ash to improve durability and long-term strength, by increasing cement mix fluidity, and a polycarboxylic superplasticizer-based admixture was used.

Table 3. Experimental parameters for setting time and early compressive strength tests using ordinary Portland cement (OPC) and high $\mathrm{SO}_{3}$ Portland cement (HSPC).

\begin{tabular}{|c|c|c|c|c|}
\hline Series & Type & Experimental Factors & Experimental Levels & Measured Parameters \\
\hline \multirow{3}{*}{ I } & \multirow{3}{*}{ Mortar } & \multirow{3}{*}{ Cement fineness and type } & $3000 \mathrm{~cm}^{2} / \mathrm{g}(\mathrm{OPC})$ & \multirow{3}{*}{$\begin{array}{c}\text { Setting time }(\mathrm{h}) \\
\text { Compressive strength }(\mathrm{MPa})\end{array}$} \\
\hline & & & $3400 \mathrm{~cm}^{2} / \mathrm{g}(\mathrm{OPC})$ & \\
\hline & & & $3800 \mathrm{~cm}^{2} / \mathrm{g}$ (OPC, HSPC) & \\
\hline \multirow{5}{*}{ II } & \multirow{5}{*}{ Concrete } & \multirow{2}{*}{ Cement fineness and type } & $3400 \mathrm{~cm}^{2} / \mathrm{g}(\mathrm{OPC})$ & \multirow{5}{*}{$\begin{array}{c}\text { Slump }(\mathrm{mm}) \\
\text { Air content }(\%) \\
\text { Compressive strength }(\mathrm{MPa}) \\
\text { Maturity }\left({ }^{\circ} \mathrm{C} \cdot \mathrm{h}\right)\end{array}$} \\
\hline & & & $3800 \mathrm{~cm}^{2} / \mathrm{g}$ (HSPC) & \\
\hline & & \multirow{3}{*}{ Curing type } & Chamber $\left(15^{\circ} \mathrm{C}\right)$ & \\
\hline & & & Indoor (variable temperature) & \\
\hline & & & Sealed (variable temperature) & \\
\hline
\end{tabular}

Table 4. Mixing proportions for mortar tests.

\begin{tabular}{ccccccc}
\hline \multicolumn{2}{c}{ Series } & W/C (\%) & C:S $^{(\mathbf{1})}$ & Cement (g) & Water (g) & AD $^{(\mathbf{2})} \mathbf{( B \times \% )}$ \\
\hline I & OPC & 50 & $1: 3$ & 450 & 225 & 0.7 \\
(Mortar) & HSPC & 50 & $1: 3$ & 450 & 225 & 0.7 \\
\hline \multicolumn{5}{c}{${ }^{(1)}$ C:S = Cement:sand (ISO standard sand); ${ }^{(2)}$ AD: Admixture. W/C: water/cement. }
\end{tabular}

Table 5. Mixing proportions for concrete tests.

\begin{tabular}{|c|c|c|c|c|c|c|c|c|c|c|c|c|}
\hline \multirow{2}{*}{\multicolumn{2}{|c|}{ Series }} & \multirow{2}{*}{$\begin{array}{c}\text { W/B } \\
(\mathbf{1})\end{array}$} & \multirow{2}{*}{$\begin{array}{c}\mathrm{S} / \mathrm{a}^{(2)} \\
(\%)\end{array}$} & \multicolumn{8}{|c|}{ Unit Weight $\left(\mathrm{kg} / \mathrm{m}^{3}\right)$} & \multirow{2}{*}{$\begin{array}{l}A D^{(8)} \\
(B \times \%)\end{array}$} \\
\hline & & & & B $^{(3)}$ & $W^{(4)}$ & OPC & HSPC & FA & S1 ${ }^{(5)}$ & $S 2^{(6)}$ & $G^{(7)}$ & \\
\hline II & OPC & 50 & 49.2 & 330 & 165 & 300 & 0 & 30 & 541 & 361 & 932 & 0.8 \\
\hline (Concrete) & HSPC & 50 & 49.2 & 330 & 165 & 0 & 300 & 30 & 541 & 361 & 932 & 0.8 \\
\hline
\end{tabular}

${ }^{(1)}$ W/B: Water/Binder; ${ }^{(2)}$ S/a: Sand/aggregates; ${ }^{(3)}$ B: Binder; ${ }^{(4)}$ W: Water; ${ }^{(5)}$ S1: Crushed sand; ${ }^{(6)}$ S2: Sea sand;

(7) G: Gravel; ${ }^{\left({ }^{8}\right)}$ AD: Polycarboxylic superplasticizer-based type admixture.

\subsection{Experimental Procedure}

In Series I, the mortar flow test was performed according to ASTM C1437 [36], and the mortar setting test according to ASTM C403/C403M [37]. The compressive strength of mortar was measured at the age specified by ASTM C109/C109M [38]. In Series II, the concrete slump test was conducted in accordance with standard ASTM C143/C143M [39], and the air content test in accordance with ASTM C231/C231M [40]. Cylindrical specimens for compressive strength $(\varnothing: 100 \times 200 \mathrm{~mm})$ were fabricated in accordance with the "Standard Test Method for Compressive Strength of Cylindrical Concrete 
Specimens", described in ASTM C39/C39M [41], and the compressive strength by elapsed time was measured. As shown in Figure 6, T-type thermocouples were installed to measure the temperature history of the specimens under each curing condition using a data logger. The model proposed in ASTM C873/C873M [42] was installed to measure the compressive strength of concrete samples and record the actual history of hydration at an early age.

Equation (5), a functional formula proposed by Nurse-Saul, was used to calculate the sample maturity according to ASTM C1074 [43-45]. Maturity theory is closely related to the strength improvement of Portland cement concrete and was first proposed by Saul in 1951, who calculated the maturity index based on the lowest temperature at which the strength could be improved [46]. Maturity theory was further refined by Bergström [47].

$$
\mathrm{M}=\sum\left(\mathrm{T}-\mathrm{T}_{0}\right) \cdot \Delta \mathrm{t}
$$

where $\mathrm{M}$ is the maturity index $\left({ }^{\circ} \mathrm{C} \cdot \mathrm{h}\right), \mathrm{T}$ is the average concrete temperature $\left({ }^{\circ} \mathrm{C}\right)$ during the time interval $\Delta \mathrm{t}(\mathrm{h}), \mathrm{T}_{0}$ is the datum temperature (typically $\left.-10{ }^{\circ} \mathrm{C}\right)$, and $\mathrm{t}$ is the elapsed time (h).

Equation (6) was used to predict the early-age strength. It is a functional formula proposed by Plowman in 1956, based on the hypothesis that the compressive strength of concrete is close to linear when expressed as a logarithmic function of maturity using the Nurse-Saul equation [48]. As this simple equation has only two constants to be determined, it is generally applicable [49]:

$$
\mathrm{f}_{\mathrm{C}}=\mathrm{a}+\mathrm{b} \cdot \ln (\mathrm{M})
$$

where $\mathrm{f}_{\mathrm{C}}$ is the compressive strength $(\mathrm{MPa}), \mathrm{M}$ is the maturity index $\left({ }^{\circ} \mathrm{C} \cdot \mathrm{h}\right)$, and a and $\mathrm{b}$ are regression constants.

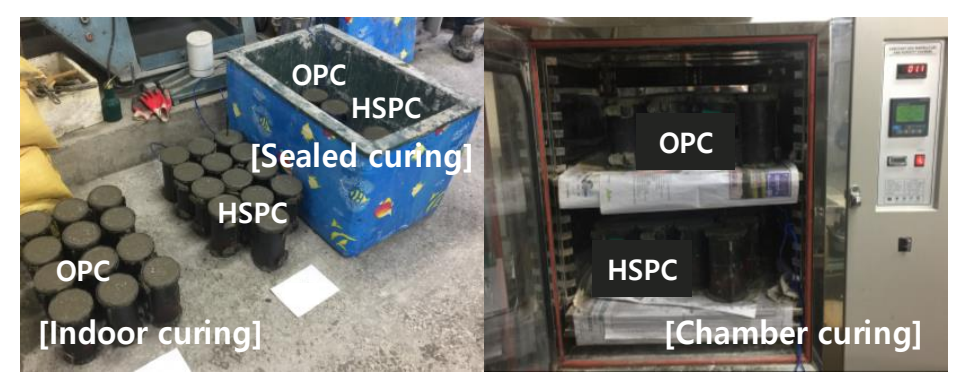

(a) (b)

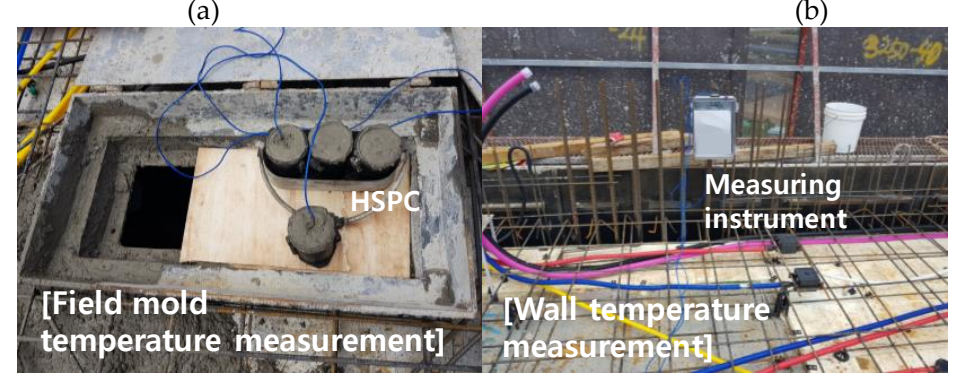

(c)

(d)

Figure 6. Photographs of the concrete curing test methods: (a) Indoor and sealed curing; (b) Chamber curing; (c) Mold temperature measurement; (d) Wall temperature measurement.

\section{Results and Discussion}

\subsection{Setting Time and Early Strength Properties of Mortar}

Figure 7 shows the OPC setting time by fineness. Initial setting time decreased by approximately $3 \mathrm{~min}$, with fineness increased by $100 \mathrm{~cm}^{2} / \mathrm{g}$, and the final setting time was reduced by $4 \mathrm{~min} 38 \mathrm{~s}$. 
At the same fineness $\left(3800 \mathrm{~cm}^{2} / \mathrm{g}\right)$, HSPC initial and final setting times were less than those of OPC by 92 and $98 \mathrm{~min}$, respectively.

Figure 8 shows the early compressive strength of OPC and HSPC by elapsed time. At the same fineness $\left(3800 \mathrm{~cm}^{2} / \mathrm{g}\right)$, the compressive strength of HSPC was higher by $146 \%, 159 \%$, and $176 \%$ after $15 \mathrm{~h}, 18 \mathrm{~h}$, and $24 \mathrm{~h}$, respectively. Figure 9 shows the early compressive strength of OPC by fineness. Early compressive strength increased with the degree of fineness. Strength improvements of $0.33 \mathrm{MPa}$, $0.46 \mathrm{MPa}$, and $0.69 \mathrm{MPa}$ were observed at $15 \mathrm{~h}, 18 \mathrm{~h}$, and $24 \mathrm{~h}$ of elapsed time, per $100 \mathrm{~cm}^{2} / \mathrm{g}$ increase in fineness.

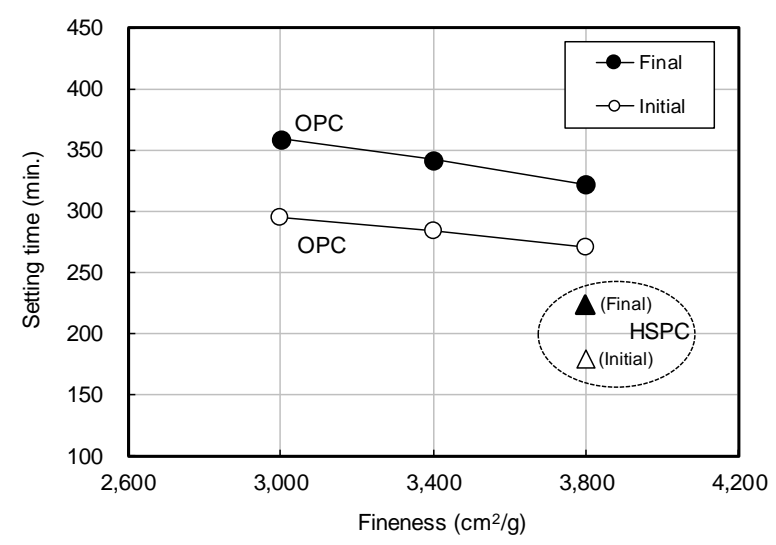

Figure 7. Setting time of OPC by fineness.

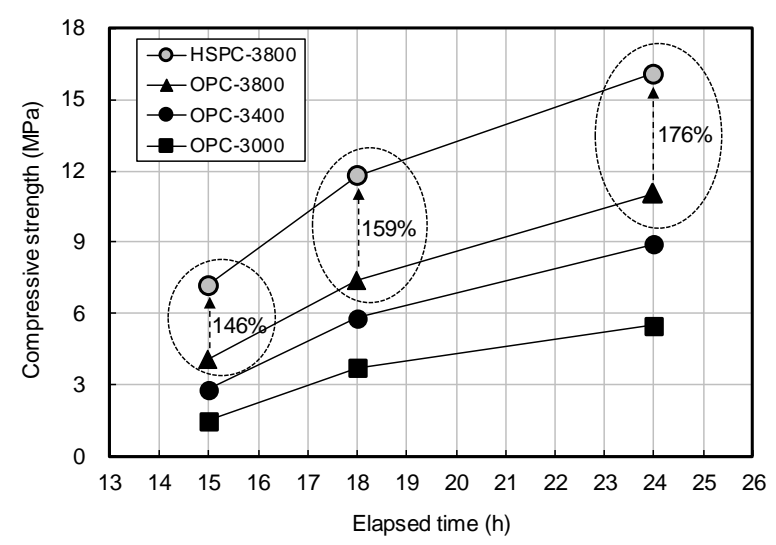

Figure 8. Early compressive strength of OPC and HSPC by elapsed time.

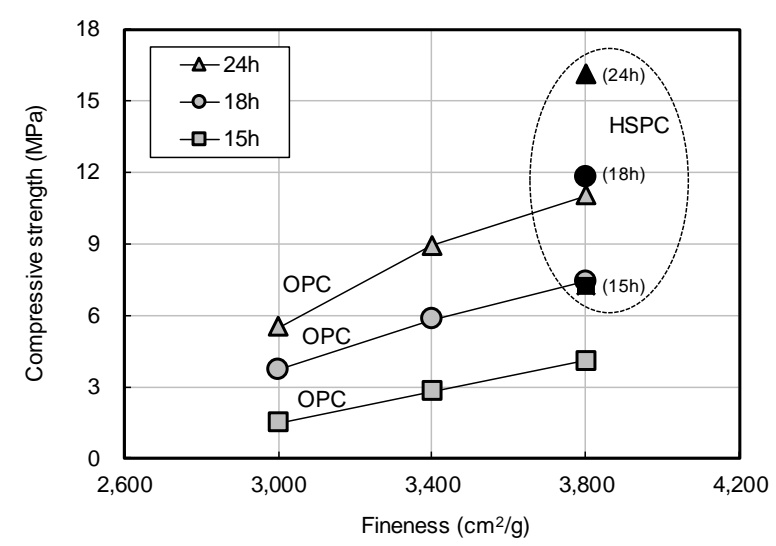

Figure 9. Early compressive strength of OPC by fineness.

Taken together, the results of Figures 7-9 showed that as the fineness of cement increased, setting time decreased, and early compressive strength increased. This might be due to enhanced activation 
of the initial hydration reaction with increasing fineness. However, at the same level of fineness, HSPC exhibited a faster setting time and higher early compressive strength than OPC. For this reason, the molar ratios $\mathrm{CaO} / \mathrm{SO}_{3}$ and $\mathrm{SO}_{3} / \mathrm{Al}_{2} \mathrm{O}_{3}$ and the hydraulic moduli of OPC and $\mathrm{HSPC}$ were reviewed (Figures 10 and 11). For HSPC relative to OPC, the $\mathrm{CaO} / \mathrm{SO}_{3}$ ratio was lower $\left(93.7 \%\right.$ ), the $\mathrm{SO}_{3} / \mathrm{Al}_{2} \mathrm{O}_{3}$ ratio was higher $(116.1 \%)$, and the hydraulic modulus $\left(\mathrm{CaO} /\left(\mathrm{SIO}_{2}+\mathrm{Al}_{2} \mathrm{O}_{3}+\mathrm{Fe}_{2} \mathrm{O}_{3}\right)\right)$ was also higher $(104.4 \%)$. These differences have implied correspondence with the faster setting time and higher early compressive strength of HSPC at the same fineness.

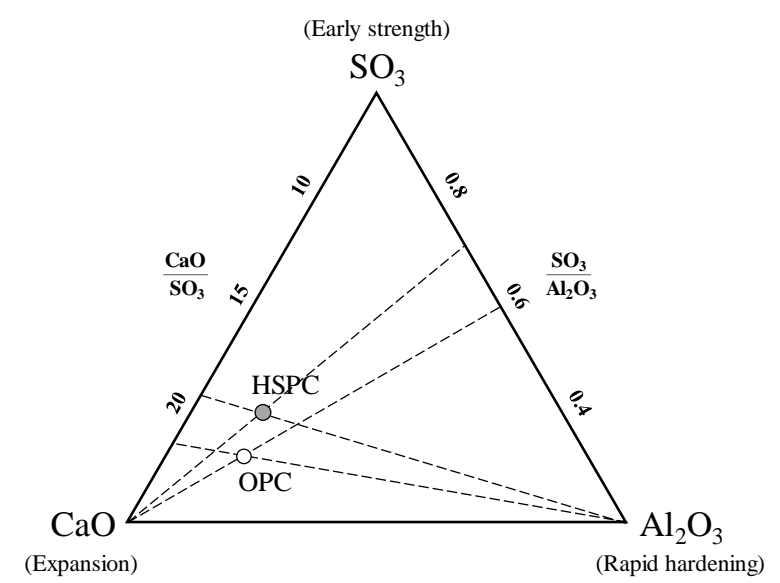

Figure 10. $\mathrm{CaO} / \mathrm{SO}_{3}$ and $\mathrm{SO}_{3} / \mathrm{Al}_{2} \mathrm{O}_{3}$ molar ratios in OPC and HSPC.
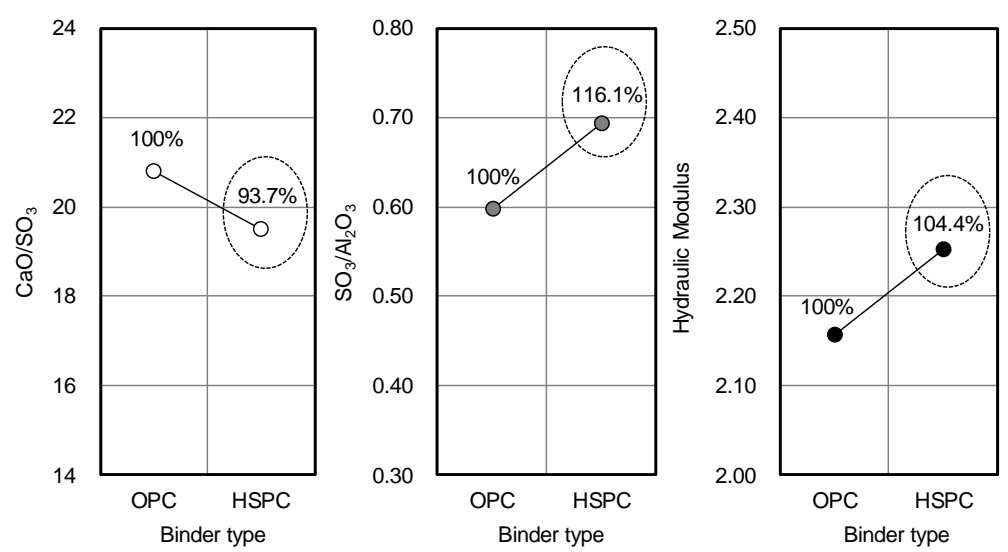

Figure 11. $\mathrm{CaO} / \mathrm{SO}_{3}, \mathrm{SO}_{3} / \mathrm{Al}_{2} \mathrm{O}_{3}$, and hydraulic modulus molar ratios in OPC and HSPC.

\subsection{Early Strength Properties of Concrete}

Fresh OPC and HSPC were produced from the batchers at Remicon S. The initial air content and slump values after production were compared with those obtained one hour after production. The test results revealed that both OPC and HSPC met the target slump and air content values of $180 \pm 25 \mathrm{~mm}$ and $4.5 \pm 1.5 \%$, respectively (Table 6 ).

Figure 12 shows the curing temperature history and maturity for concrete samples under the three curing methods. The order of maturity after $24 \mathrm{~h}$ was HSPC concrete $>$ Air $>$ OPC concrete, regardless of the method. The indoor curing results after $24 \mathrm{~h}$ (Figure 12a) showed that HSPC concrete maturity $\left(644.6{ }^{\circ} \mathrm{C} \cdot \mathrm{h}\right)$ was $103 \%$ higher than air $\left(625.8^{\circ} \mathrm{C} \cdot \mathrm{h}\right)$, whereas OPC concrete $\left(608.6^{\circ} \mathrm{C} \cdot \mathrm{h}\right)$ was as low as $97.2 \%$. The sealed curing results after $24 \mathrm{~h}$ (Figure $12 \mathrm{~b}$ ) showed that HSPC concrete maturity $\left(762.5^{\circ} \mathrm{C} \cdot \mathrm{h}\right)$ was $104.6 \%$ higher than air $\left(729.2^{\circ} \mathrm{C} \cdot \mathrm{h}\right)$, whereas OPC concrete $\left(719.2{ }^{\circ} \mathrm{C} \cdot \mathrm{h}\right)$ was at $98.6 \%$. The chamber curing results after $24 \mathrm{~h}$ (Figure 12c) showed that HSPC concrete maturity $\left(672.7^{\circ} \mathrm{C} \cdot \mathrm{h}\right.$ ) was $108.8 \%$ higher than air $\left(618.6^{\circ} \mathrm{C} \cdot \mathrm{h}\right)$, while OPC concrete $\left(602.1^{\circ} \mathrm{C} \cdot \mathrm{h}\right)$ was $97.3 \%$ of the air value. 


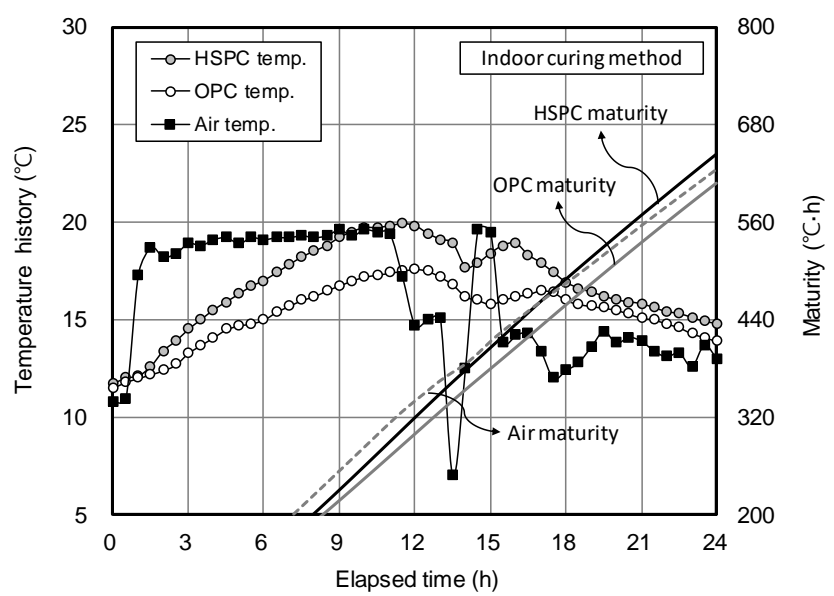

(a)

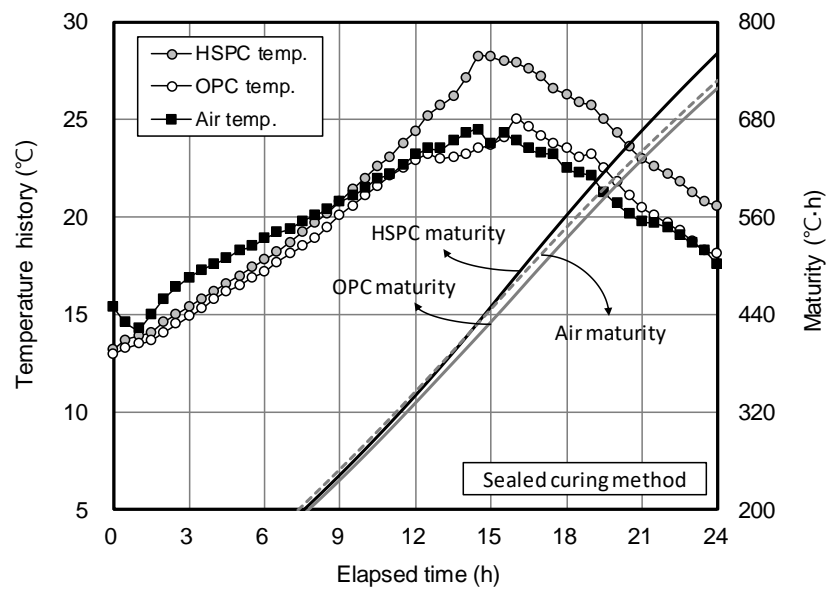

(b)

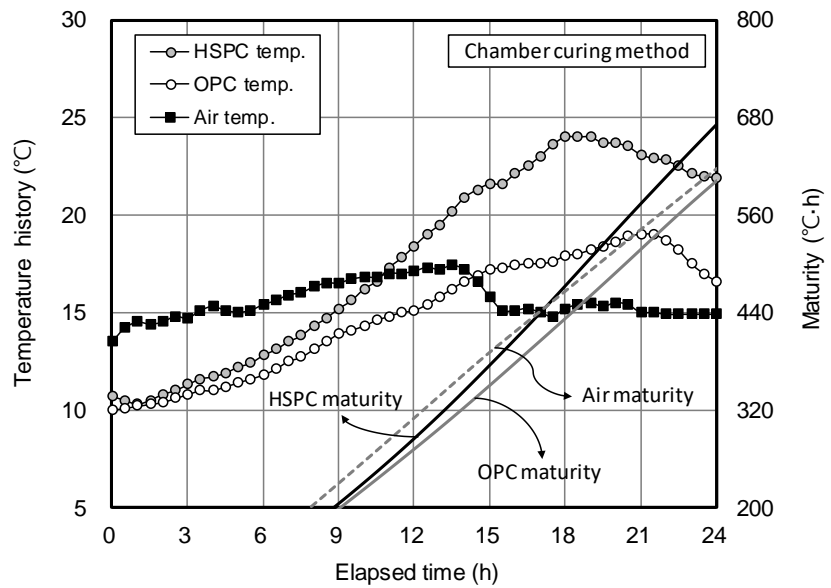

(c)

Figure 12. Concrete curing temperature history and maturity for different curing methods: (a) Indoor curing method; (b) Sealed curing method; (c) Chamber curing method.

Figure 13 compares the maturity and early strength of OPC and HSPC concrete. At elapsed times of $15 \mathrm{~h}, 18 \mathrm{~h}$, and $24 \mathrm{~h}$, the maturity of HSPC concrete was $107.4 \%, 109.6 \%$, and $111.7 \%$ higher than that of OPC concrete, and the early compressive strength was $146.4 \%, 170.7 \%$, and $154.5 \%$ higher. 
The differences in HSPC over OPC were, firstly, higher fineness (111.8\%), leading to early activation of the hydration reaction; secondly, higher $\mathrm{SO}_{3}$ content $(107.9 \%)$ as measured by X-ray fluorescence analysis (Figure 14); thirdly, $\mathrm{CaO} / \mathrm{SO}_{3}$ was low, and $\mathrm{SO}_{3} / \mathrm{Al}_{2} \mathrm{O}_{3}$ and hydraulic modulus were high (Figures 10 and 11). As a result, the heat of hydration and maturity of HSPC concrete were higher than those of OPC under the same mixing and curing conditions (Figure 12), leading to higher early compressive strength.

Table 6. Properties of fresh concrete.

\begin{tabular}{cccccc}
\hline \multirow{2}{*}{ Series } & \multicolumn{2}{c}{ Air (\%) } & \multicolumn{2}{c}{ Slump (mm) } \\
\cline { 2 - 6 } & & Initial & $\mathbf{1 ~ h}$ & Initial & $\mathbf{1 ~ h}$ \\
\hline II & OPC & 4.6 & 4.3 & 165 & 170 \\
(Concrete) & HSPC & 3.8 & 3.5 & 185 & 185 \\
\hline
\end{tabular}

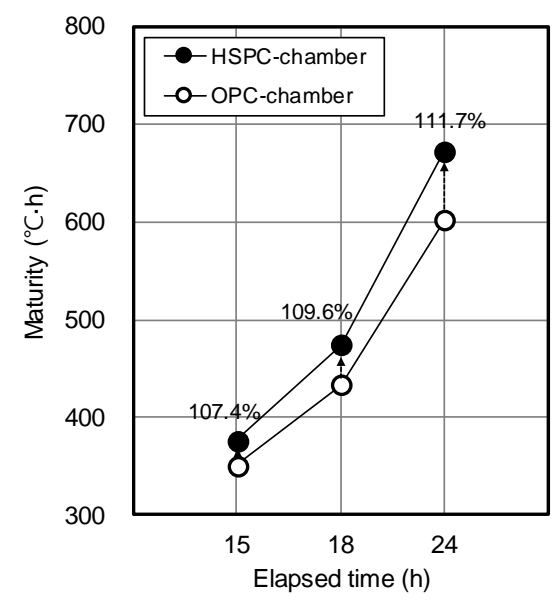

(a)

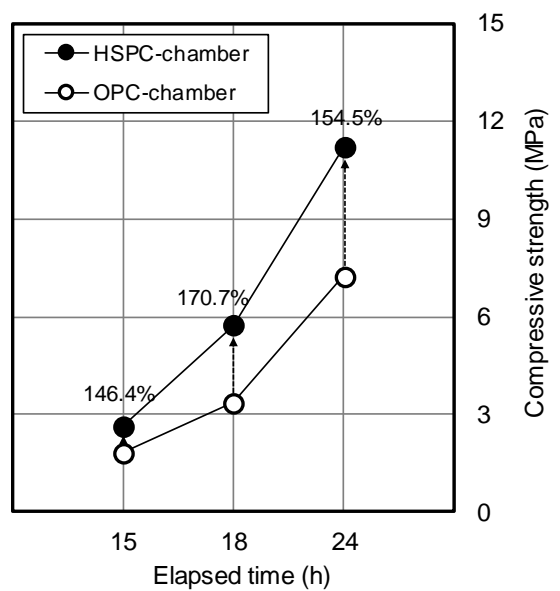

(b)

Figure 13. Comparison of maturity and early strength of OPC and HSPC concrete: (a) Maturity; (b) Early compressive strength.

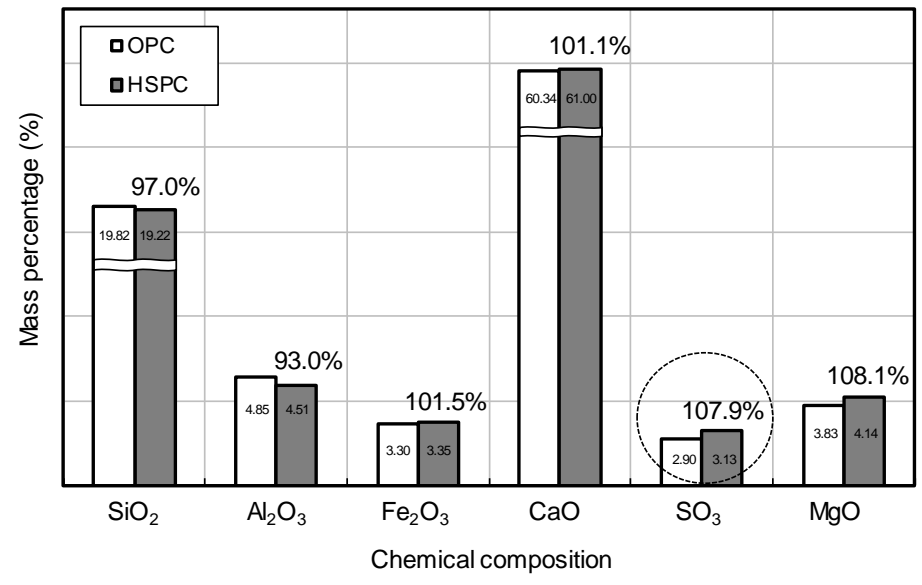

Figure 14. X-ray fluorescence analysis results of OPC and HSPC.

Figure 15 shows the strength enhancement curves for OPC and HSPC concrete, derived by applying the functional formula proposed by Plowman (Equation (6)). The strength enhancement curves for OPC and HSPC are modeled as $y=11.78 \ln (x)-67.35$ and $y=16.99 \ln (x)-98.14$, respectively, with high correlations of $95 \%$ and $96 \%$. At the maturity of $400-800{ }^{\circ} \mathrm{C} \cdot \mathrm{h}$, the slope of the HSPC concrete strength enhancement curve was $144.2 \%$ that of OPC concrete. The most important element for reducing the number of cycles per floor for a typical apartment construction site is the time required to reach a 
compressive strength of $5 \mathrm{MPa}$, at which point form removal is possible [50]. OPC concrete reached $5 \mathrm{MPa}$ at $465^{\circ} \mathrm{C} \cdot \mathrm{h}$, and $\mathrm{HSPC}$ concrete reached $5 \mathrm{MPa}$ at $433^{\circ} \mathrm{C} \cdot \mathrm{h}$ maturity; therefore, the application of HSPC to actual construction sites could enable form removal at approximately $6.9 \%$ lower maturity than OPC.

Figure 16 compares the estimated strength curve (ESC) for HSPC concrete, based on the temperature history curve of the field molds, with the measured compressive strength of the field molds. The actual compressive strengths of all six field molds of HSPC were within $\pm 10 \%$ of the ESC. Therefore, the reliability of the ESC for HSPC concrete was assumed to be $90 \%$ or higher.

Figure 17 shows the ESC for the HSPC concrete samples according to the temperatures of the mold, curing air, and structure wall (200 mm thick). For a curing time of 9-18 h, the average maturity values of the field mold, curing air, and structure wall were $496{ }^{\circ} \mathrm{C} \cdot \mathrm{h}(96.6 \%), 514{ }^{\circ} \mathrm{C} \cdot \mathrm{h}(100 \%)$, and $550{ }^{\circ} \mathrm{C} \cdot \mathrm{h}$ $(107 \%)$, indicating that curing in the structure wall resulted in approximately $10.8 \%$ higher hydration heat than the mold. Therefore, a safety factor of approximately $10.8 \%$ could be assumed if vertical form removal is performed at a time based on the attainment of $5 \mathrm{MPa}$ compressive strength in the mold. The compressive strengths of the field mold, curing air, and structure wall reached $5 \mathrm{MPa}$ after $11.8 \mathrm{~h}, 11.3 \mathrm{~h}$, and $11 \mathrm{~h}$, indicating that the applicable time of form removal for the structure wall was approximately $48 \mathrm{~min}$ earlier than that of the mold (i.e., without the $10.8 \%$ safety factor).

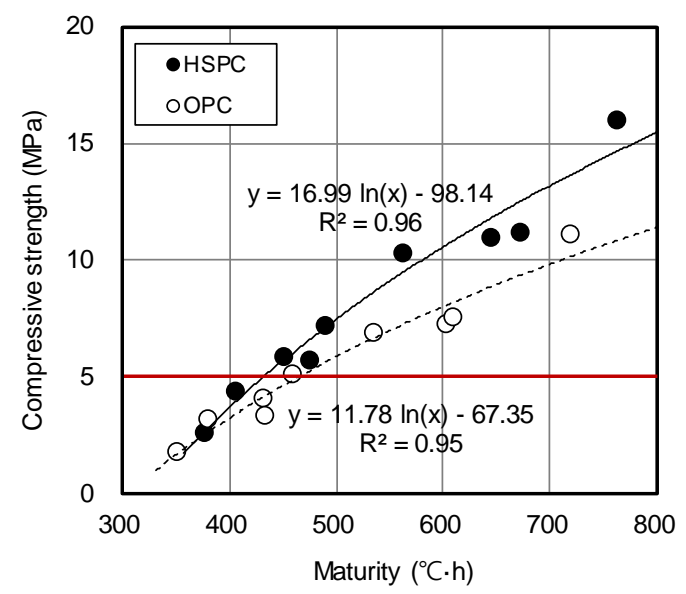

Figure 15. Derived strength enhancement curves of OPC and HSPC concrete.

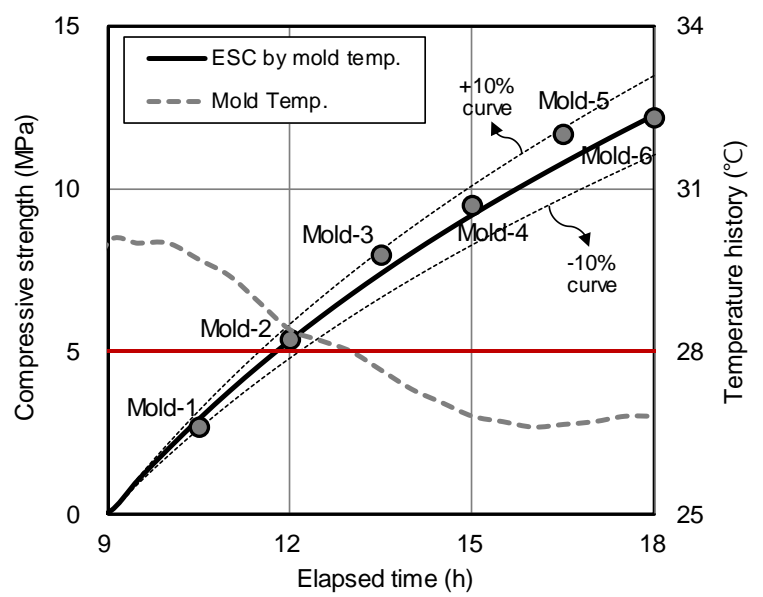

Figure 16. Comparison of the estimated strength curve (ESC) and measured compressive strength of the field mold of HSPC concrete. 


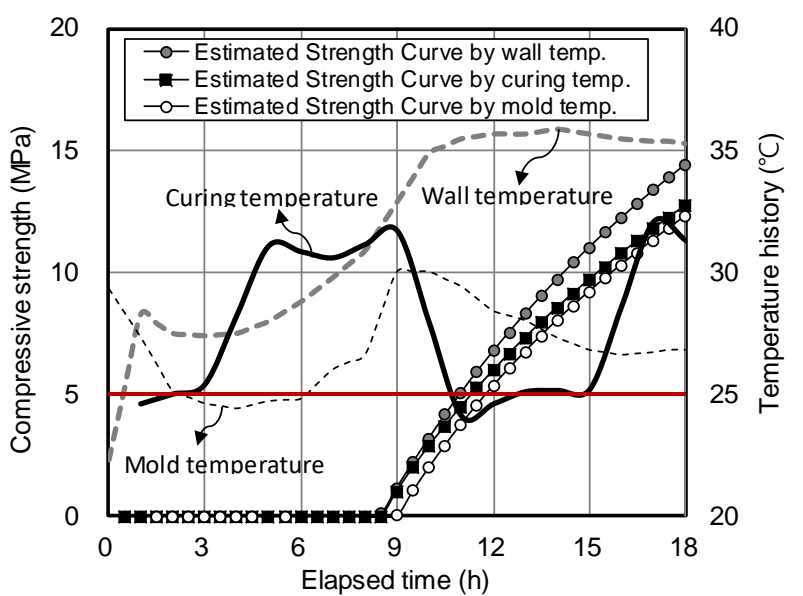

Figure 17. Estimated strength curve and temperature history for the structure wall, field mold, and curing air according to the curing elapsed time of HSPC concrete.

Figure 18 shows the estimated applicable time of form removal according to the average temperature history of the concrete. Relationships of $y=-10.57 \ln (x)+47.30$ and $y=-9.84 \ln (x)$ +44.05 were estimated for OPC and HSPC, respectively, with high correlations of $99.4 \%$ calculated for both. ACI 347R Guide to Formwork for Concrete [51] requires that the wall vertical formwork be retained for $12 \mathrm{~h}$ under conditions where the temperature of the air surrounding the concrete is above $50^{\circ} \mathrm{F}\left(10^{\circ} \mathrm{C}\right)$. However, in the case of domestic construction sites, the wall vertical formwork is often removed at 8 am the day after the ready-mixed concrete is poured, which is normally completed by $2 \mathrm{pm}$. Therefore, this study assumed that the target vertical form removal time was $18 \mathrm{~h}$ after concrete pouring. This required an average curing temperature greater than $15.8^{\circ} \mathrm{C}$ for $\mathrm{OPC}$ and $14{ }^{\circ} \mathrm{C}$ for HSPC. Therefore, the strength required for form removal could be achieved at a $1.8^{\circ} \mathrm{C}$ lower curing temperature by employing HSPC concrete. As the curing temperature might be reduced during construction in winter, this would enable a reduction of heat curing costs.

Figure 19 illustrates the length of time for which heat curing would not be required to ensure the strength needed for form removal (5 MPa) within $18 \mathrm{~h}$ after concrete pouring by applying HSPC. This length of time was calculated by analyzing the monthly average temperatures of Busan in Korea for the last five years. Busan is a metropolitan city in the south of Korea and has a project that will actually apply HSPC. It was found that heat curing would not be necessary from early April to the end of October (approximately 6.8 months) when using HSPC; however, measures, such as heat curing, would be required for the remaining 5.2 months to ensure an average curing temperature of $14{ }^{\circ} \mathrm{C}$ or higher.

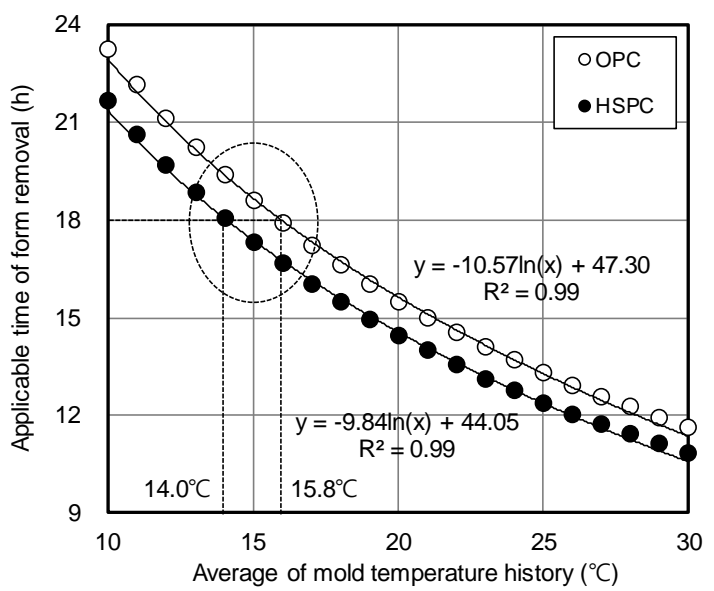

Figure 18. Applicable time of form removal according to the average temperature history of field mold. 


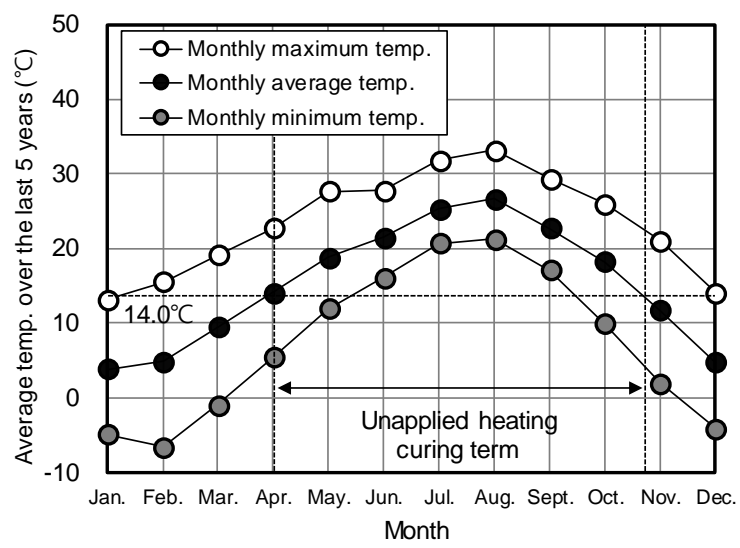

Figure 19. Months when heat curing would not be required in Busan due to using HSPC concrete.

\section{Conclusions}

In this study, the influences of chemical composition and fineness on the development of concrete strength by curing conditions were investigated through the performance evaluation of HSPC and OPC. The early compressive strength of HSPC was predicted, and its application to actual construction sites was examined. The main conclusions are as follows.

(1) According to the Series I (mortar) test, increasing the fineness of OPC resulted in faster setting time and early compressive strength. At the same fineness $\left(3800 \mathrm{~cm}^{2} / \mathrm{g}\right)$, the initial and final setting times of HSPC were 92 and 98 min less than OPC, and the early compressive strength was approximately $176 \%$ higher after $24 \mathrm{~h}$ curing.

(2) $\mathrm{HSPC} \mathrm{CaO} / \mathrm{SO}_{3}$ molar ratio was lower (93.7\%), $\mathrm{SO}_{3} / \mathrm{Al}_{2} \mathrm{O}_{3}$ was higher $(116.1 \%)$, and the hydraulic modulus was $104.4 \%$ higher than OPC.

(3) According to the Series II (concrete) test, the maturity at elapsed time $24 \mathrm{~h}$ was HSPC $>$ Air $>$ OPC, regardless of the curing method. At elapsed times of $15 \mathrm{~h}, 18 \mathrm{~h}$, and $24 \mathrm{~h}$, the maturity of HSPC concrete was $107.4 \%, 109.6 \%$, and $111.7 \%$ higher than OPC concrete, and the early compressive strengths were $146.4 \%, 170.7 \%$, and $154.5 \%$ higher.

(4) The reasons for the improvement were that the fineness of HSPC was approximately $111.8 \%$ (400 $\mathrm{cm}^{2} / \mathrm{g}$ increase) greater than OPC, leading to early activation of the hydration reaction, and by the results of X-ray fluorescence analysis, $\mathrm{HSPC}$ had $107.9 \%$ higher $\mathrm{SO}_{3}$ content. The heat of hydration and maturity of HSPC were higher than that of OPC under the same mixing and curing conditions.

(5) The applicable time of form removal was estimated according to the average temperature history of the field molds. Relationships of $y=-10.57 \ln (x)+47.30$ and $y=-9.84 \ln (x)+44.05$ were estimated for OPC and HSPC concrete, respectively. The average curing temperature must be $15.8^{\circ} \mathrm{C}$ or higher for OPC and $14{ }^{\circ} \mathrm{C}$ or higher for HSPC to ensure $5 \mathrm{MPa}$ within $18 \mathrm{~h}$ after concrete pouring.

Based on the monthly average temperatures in Busan, Korea, for the last five years, heat curing would not be required from early April to the end of October (approximately 6.8 months). During the remaining months, measures, such as heat curing, would be required to maintain average curing temperatures of $14^{\circ} \mathrm{C}$ or higher for HSPC.

In future studies, the performance impact of HSPC according to mineralogical composition would be investigated, and the effects of the construction period and cost reduction effects would be examined when HSPC is applied to actual construction sites.

Author Contributions: Conceptualization, J.L. and T.L.; investigation, J.L. and T.L.; resources, J.L.; writingoriginal-draft, J.L.; writing-review and editing, J.L. and T.L.

Funding: This research received no external funding. 
Conflicts of Interest: The authors declare no conflict of interest.

\section{References}

1. Amudhavalli, N.K.; Mathew, J. Effect of silica fume on strength and durability parameters of concrete. Int. J. Eng. Sci. Emerg. Technol. 2012, 3, 28-35.

2. Golewski, G.L. The influence of microcrack width on the mechanical parameters in concrete with the addition of fly ash: Consideration of technological and ecological benefits. Constr. Build. Mater. 2019, 197, 849-861. [CrossRef]

3. Laplante, P.; Roussel, S.; Lecrux, S. Technique maturométrique: La loi d'Arrhenius au service des chantiers. In International RILEM Conference on Concrete: From Material to Structure; RILEM Publications SARL: Bagneux, France, 1996; pp. 323-342.

4. Kang, S.H.; Lee, J.H.; Hong, S.G.; Moon, J. Microstructural investigation of heat-treated ultra-high performance concrete for optimum production. Materials 2017, 10, 1106. [CrossRef] [PubMed]

5. Yikici, T.A.; Chen, H.L.R. Use of maturity method to estimate compressive strength of mass concrete. Constr. Build. Mater. 2015, 95, 802-812. [CrossRef]

6. Li, X.F.; Fu, Z.; Luo, Z.; Li, S. Concrete strength estimation using the maturity method. In Advanced Materials Research; Trans Tech Publications: Zurich, Switzerland, 2014; Volume 857, pp. 35-41.

7. Kamkar, S.; Eren, Ö. Evaluation of maturity method for steel fiber reinforced concrete. KSCE J. Civ. Eng. 2018, 22, 213-221. [CrossRef]

8. Galobardes, I.; Cavalaro, S.H.; Goodier, C.I.; Austin, S.; Rueda, Á. Maturity method to predict the evolution of the properties of sprayed concrete. Constr. Build. Mater. 2015, 79, 357-369. [CrossRef]

9. Xu, G.; Tian, Q.; Miao, J.; Liu, J. Early-age hydration and mechanical properties of high volume slag and fly ash concrete at different curing temperatures. Constr. Build. Mater. 2017, 149, 367-377. [CrossRef]

10. Carette, J.; Staquet, S. Monitoring and modelling the early age and hardening behaviour of eco-concrete through continuous non-destructive measurements: Part II. Mechanical behaviour. Cem. Concr. Compos. 2016, 73, 1-9. [CrossRef]

11. Akasaki, J.; Moraes, M.; Silva, C.; Fioriti, C.; Tashima, M. Assessment the maturity concept in concrete with the addition of rice husk ash. Revista Ingeniería de Construcción 2016, 31, 175-182. [CrossRef]

12. Zhang, Y.M.; Napier-Munn, T.J. Effects of particle size distribution, surface area and chemical composition on Portland cement strength. Powder Technol. 1995, 83, 245-252. [CrossRef]

13. Tiecher, F.; Gomes, M.; Dal Molin, D.; Hasparyk, N.; Monteiro, P. Relationship between degree of deformation in quartz and silica dissolution for the development of alkali-silica reaction in concrete. Materials 2017, 10, 1022. [CrossRef] [PubMed]

14. Celik, I.B. The effects of particle size distribution and surface area upon cement strength development. Powder Technol. 2009, 188, 272-276. [CrossRef]

15. Lee, J.H.; Lee, T.G. Effects of high CaO fly ash and sulfate activator as a finer binder for cementless grouting material. Materials 2019, 12, 3664. [CrossRef]

16. Mindess, S.; Young, J.F.; Darwin, D. Concrete; Prentice-Hall: Englewood Cliffs, NJ, USA, 1981; p. 481.

17. Szelag, M. Properties of cracking patterns of multi-walled carbon nanotube-reinforced cement matrix. Materials 2019, 12, 2942. [CrossRef]

18. Bentz, D.P.; Sant, G.; Weiss, J. Early-age properties of cement-based materials. I: Influence of cement fineness. J. Mater. Civ. Eng. 2008, 20, 502-508. [CrossRef]

19. Zhang, Y.; Kong, X. Correlations of the dispersing capability of NSF and PCE types of superplasticizer and their impacts on cement hydration with the adsorption in fresh cement pastes. Cem. Concr. Res. 2015, 69, 1-9. [CrossRef]

20. Zhang, Y.R.; Kong, X.M.; Lu, Z.B.; Lu, Z.C.; Hou, S.S. Effects of the charge characteristics of polycarboxylate superplasticizers on the adsorption and the retardation in cement pastes. Cem. Concr. Res. 2015, 67, 184-196. [CrossRef]

21. Tan, H.; Zou, F.; Ma, B.; Liu, M.; Li, X.; Jian, S. Effect of sodium tripolyphosphate on adsorbing behavior of polycarboxylate superplasticizer. Constr. Build. Mater. 2016, 126, 617-623. [CrossRef] 
22. Tan, H.; Ma, B.; Li, X.; Jian, S.; Yang, H. Effect of competitive adsorption between sodium tripolyphosphate and naphthalene superplasticizer on fluidity of cement paste. J. Wuhan Univ. Technol. Mater. Sci. Ed. 2014, 29, 334-340. [CrossRef]

23. Škvára, F.; Kolář, K.; Novotný, J.; Zadák, Z. The effect of cement particle size distribution upon properties of pastes and mortars with low water-to-cement ratio. Cem. Concr. Res. 1981, 11, 247-255. [CrossRef]

24. Sabir, B.B.; Wild, S.; Bai, J. Metakaolin and calcined clays as pozzolans for concrete: A review. Cem. Concr. Compos. 2001, 23, 441-454. [CrossRef]

25. Lee, B.K.; Kim, G.Y.; Nam, J.S.; Lee, K.H.; Kim, G.T.; Lee, S.K.; Shin, K.S.; Koyama, T. Influence of $\alpha$-calcium sulfate hemihydrate on setting, compressive strength, and shrinkage strain of cement mortar. Materials 2019, 12, 163. [CrossRef] [PubMed]

26. Soroka, I.; Abayneh, M. Effect of gypsum on properties and internal structure of PC paste. Cem. Constr. Res. 1986, 16, 495-504. [CrossRef]

27. Kim, J.H.; Lee, H.S. Improvement of early strength of cement mortar containing granulated blast furnace slag using industrial byproducts. Materials 2017, 10, 1050. [CrossRef]

28. Mardani-Aghabaglou, A.; Boyaci, O.C.; Hosseinnezhad, H.; Felekog`lu, B.; Ramyar, K. Effect of gypsum type on properties of cementitious materials containing high range water reducing admixture. Cem. Concr. Compos. 2016, 68, 15-26. [CrossRef]

29. European Committee for Standardization. EN 197-1 Cement-Part 1: Composition, Specifications and Conformity Criteria for Common Cements; CEN/TC 51: Brussels, Belgium, 2000.

30. Liu, F.; Lan, M.Z. Effects of gypsum on cementitious systems with different mineral mixtures. Key Eng. Mater. 2012, 509, 20-25. [CrossRef]

31. Lee, J.H.; Kim, G.Y.; Kim, Y.R.; Mun, K.J.; Nam, J.S. Engineering properties and optimal conditions of cementless grouting materials. Materials 2019, 12, 3059. [CrossRef]

32. Kurdowski, W. Chapter 4: Cement Hydration. In Cement and Concrete Chemistry; Springer Science \& Business: New York, NY, USA, 2014; pp. 205-277.

33. Mohammed, S.; Safiullah, O. Optimization of the $\mathrm{SO}_{3}$ content of an Algerian Portland cement: Study on the effect of various amounts of gypsum on cement properties. Constr. Build Mater. 2018, 164, 362-370. [CrossRef]

34. Korean Industrial Standards. Portland Cement. KS L 5201; Korean Agency for Technology and Standards: Seoul, Korea, 2016.

35. American Society for Testing and Materials. ASTM C778 Standard Specification for Standard Sand; ASTM: West Conshohocken, PA, USA, 2017.

36. American Society for Testing and Materials. ASTM C1437 Standard Test Method for Flow of Hydraulic Cement Mortar; ASTM: West Conshohocken, PA, USA, 2015.

37. American Society for Testing and Materials. ASTM C403/C403M Standard Test Method for Time of Setting of Concrete Mixtures by Penetration Resistance; ASTM: West Conshohocken, PA, USA, 2016.

38. American Society for Testing and Materials. ASTM C109/C109M Standard Test Method for Compressive Strength of Hydraulic Cement Mortars; ASTM: West Conshohocken, PA, USA, 2017.

39. American Society for Testing and Materials. ASTM C143/C143M Standard Test Method for Slump of Hydraulic-Cement Concrete; ASTM: West Conshohocken, PA, USA, 2015.

40. American Society for Testing and Materials. ASTM C231/C231M Standard Test Method for Air Content of Freshly Mixed Concrete by the Pressure Method; ASTM: West Conshohocken, PA, USA, 2017.

41. American Society for Testing and Materials. ASTM C39/C39M Standard Test Method for Compressive Strength of Cylindrical Concrete Specimens; ASTM: West Conshohocken, PA, USA, 2018.

42. American Society for Testing and Materials. ASTM C873/C873M Standard Test Method for Compressive Strength of Concrete Cylinders Cast in Place in Cylindrical Molds; ASTM: West Conshohocken, PA, USA, 2015.

43. American Society for Testing and Materials. ASTM C1074 Standard Practice for Estimating Concrete Strength by the Maturity Method; ASTM: West Conshohocken, PA, USA, 2019.

44. Carino, N.J.; Lew, H.S. Maturity method: From theory to application. In Reprinted from the Proceedings of the 2001 Structures Congress \& Exposition, Washington, DC, USA, 21-23 May 2001; Peter, C., Ed.; American Society of Civil Engineers: Reston, VA, USA, 2001.

45. Soutsos, M.N.; Turu'allo, G.; Owens, K.; Kwasny, J.; Barnett, S.J.; Basheer, P.A.M. Maturity testing of lightweight self-compacting and vibrated concretes. Constr. Build. Mater. 2013, 47, 118-125. [CrossRef] 
46. Saul, A.G.A. Principles underlying the steam curing of concrete at atmospheric pressure. Mag. Concr. Res. 1951, 2, 127-140. [CrossRef]

47. Bergström, S.G. Curing temperature, age and strength of concrete. Mag. Concr. Res. 1953, 5, 61-66. [CrossRef]

48. Plowman, J. Maturity and the strength of concrete. Mag. Concr. Res. 1956, 8, 13-22. [CrossRef]

49. Jin, N.J.; Seung, I.; Choi, Y.S.; Yeon, J. Prediction of early-age compressive strength of epoxy resin concrete using the maturity method. Constr. Build. Mater. 2017, 152, 990-998. [CrossRef]

50. Korean Construction Specification. Formwork and Construction Work General. KCS 2150 05; Korean Construction Standards Center: Seoul, Korea, 2018.

51. American Concrete Institute Committee 347. ACI347-04 Guide to Formwork for Concrete; ACI: Farmington Hills, MI, USA, 2004.

(C) 2019 by the authors. Licensee MDPI, Basel, Switzerland. This article is an open access article distributed under the terms and conditions of the Creative Commons Attribution (CC BY) license (http://creativecommons.org/licenses/by/4.0/). 